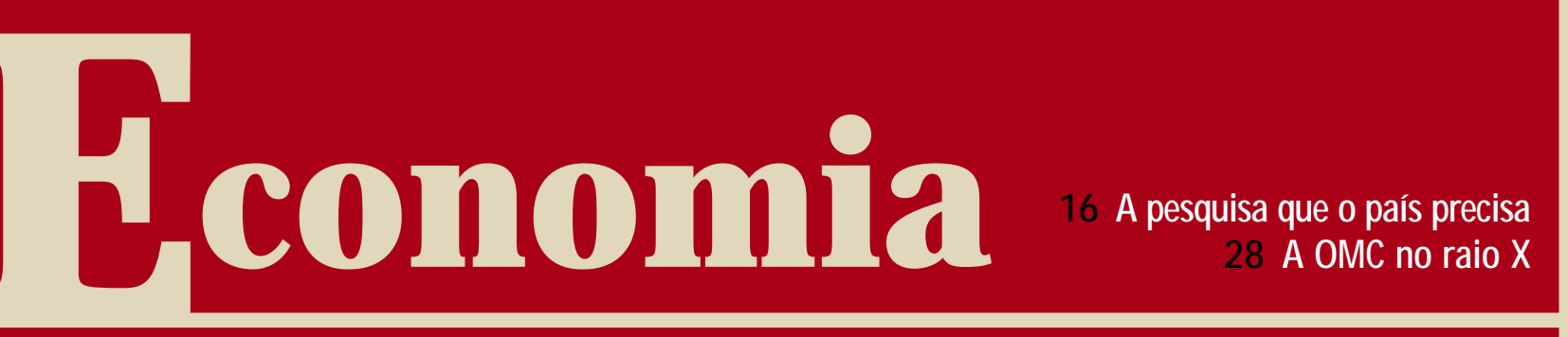

\title{
A volta do dragão de Comodo?
}

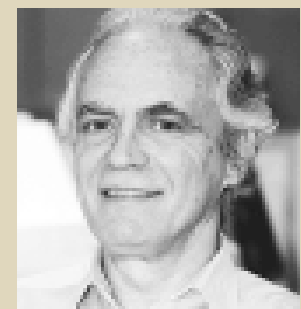

Paulo H. Sandroni FGV-EAESP

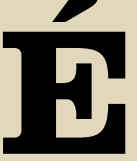

difícil escapar de uma mordida do dragão deComodo. Habitando ilhas homônimas da Indonésia, o enorme lagarto infecta com saliva a vítima atacada. Mesmo animais de grande porte, como o búfaIo, acabam morrendo pelo envenenamento. 0 sangue circula, as bactérias vão penetrando inapelavelmente nos órgãos vitais. Prostrada, a vítima acaba sendo calmamente devorada. Os humanos atacados geralmente morrem, pois não existe ainda uma cura para esse tipo de infecção, embora existam alguns casos raros de pessoas mordidas que sobreviveram.

Creio que nossa economia, neste início de 2003, está sofrendo as conseqüências de uma mordida desferida em 1999 e agravada pela febre especulativa do segundo semestre de 2002. Não que vá morrer, mas alguns "órgãos vitais" estão seriamente contaminados. 0 principal deles são as contas do governo. A sustentação de um real valorizado, até 1999 , obrigou o governo a realizar piruetas com a taxa de juros. Esta chegou a roçar a marca estratosférica de 50\% durante as crises asiática e russa, entre 1997 e 1998. Nitroglicerina também pode ser produzida com o binômio déficit público elevado etaxa de juros nas nuvens. A mistura, além de explosiva, é altamente instável. Q ual quer solavanco e a economia vai pelos ares. A dívida pública foi sofrendo sucessivas convulsões até ultrapassar a marca simbólica dos $50 \%$ do PIB. É fácil imaginar a metade de al guma coisa, apesar de ser difí- cil, às vezes, visualizar o que seja o PIB. Infelizmente, as coisas não pararam por aí.

Dos $50 \%$ saltamos para os $60 \%$, depois que o período pré-eleitoral e o pequeno pânico provocado por um punhado de espertalhões fez com que a taxa de câmbio disparasse, obrigando o governo uma vez mais a emitir títulos da dívida pública com correção cambial. Isso é uma espécie de gás sarin para a dívida: se não mata, aleija. A dívida começa a crescer a partir dos déficits provocados pelos juros que incidem sobre ela. E, como dizia Ionesco, basta acariciar um círculo para que ele se transforme em círculo vicioso. Nisso estamos. Alguns alegam, com uma certa felicidade ingênua, que a inflação provocada pela desvalorização cambial fará com que a dívida - medida em reais - se desvalorize. Mas é o mesmo que latir no quintal para economizar o cachorro, pois as taxas de juros deverão ser aumentadas para compensar os investidores em títulos públicos, para os quais o que vale são os juros reais e não os nominais. Juros em el evação significam perigo à vista: não pode haver maior desestímulo aos investimentos e ao consumo - lâminas da tesoura econômica capaz de recortar um PIB crescente.

Espremendo tudo isso, chega-se a uma amarga conclusão: embora com vocação genética para um crescimento substantivo, a economia brasileira parece uma espécie de Prometeu acorrentado, condenada a não ultrapassar os medíocres $2,5 \%$. 